read a paper on "Conifers in English Gardens," and illustrated her remarks by a large number of specimens; great interest was shown by the delegates in this popular exposition of native and introduced conifers. A third botanical paper was by Prof. G. S. Boulger on "The Origin of the English Flora."

The Silchester rooms at the Reading Museum were crowded when Mr. Mill Stephenson gave a demonstration on the Silchester discoveries. The thoroughness with which the excavations were carried out revealed a complete picture of Romano-British life, including temple, baths, silver refinery, amphitheatre, hypocaust, dwellings, latrines, and all that went to make up a centre of commercial life of the period. The cemetery remains unexcavated. The city is now again buried, the walls alone showing, whilst outside there still remain the earthworks of an earlier period still, when Neolithic Britons planned a camp of wider dimensions. Roman ornaments in bronze called for special notice, these being beautifully executed. A carpenter's plane was remarkable in that it was of metal, and included screws for adjusting the blade. A visit to Silchester enabled many members to pick up fragments of Roman brick and Gaulish ware. Regret that no portions of the buildings or the foundations had been left uncovered was expressed. It is inconceivable that our British Pompeii was again buried out of sight almost as soon as it was excavated.

A visit to Windsor enabled members to see St. George's Chapel and the King's library and to ascend the Round Tower. Papers were read by the Hon. J. W. Fortescue and Dr. A. V. Baillie. A popular lecture was given by Mr. H. E. Peake on "Racial Types in South-East England," and this gave rise to an animated discussion as to whether all the portions of the Eoanthropus skull had been properly fitted as parts of one and the same skull. It was pointed out that portions of at least three individuals had been found. A paper by Prof. John Percival on "Species and Races of Wheat" was of valuable economic interest. Growing plants of Aegilops ovata were exhibited and the part it has taken in the evolution of modern wheat expounded. Specimens of various wheats were shown, including the hard, snow-resisting Triticum spelta.

The afternoon excursions included a visit to the relics of Reading Abbey, of which the Chapter House is the most important and extensive. The hall measured $79 \mathrm{ft}$. by $42 \mathrm{ft}$. One of the tablets on the wall commemorates that ancient musical composition, "Sumer is icumen in," which is stated to have been written down at the abbey about A.D. 1240. A visit to the economic garden of Dr. J. B. Hurry showed the great care here exercised to make the garden of an educational nature. The medicinal plants growing numbered twenty-five, food plants twenty, fabric plants eleven, and dye plants twenty; whilst the herbal garden contained a very large number of useful plants which were grown extensively in the Middle Ages, and alluded to by Chaucer, Spenser, Shakespeare, and others. In the museum attached were many commercial derivatives from the plants. A fine fabric made from the common nettle was noticeable. Archæologists paid an afternoon visit to the quaint Upton Court, with its many-gabled roofs and its hidden priest-holes, and to Padworth and Aldermaston churches, when Mr. C. E. Keyser acted as guide. The University College was also visited, after which the party proceeded to the Experimental Gardens at Shinfield.

It is worthy of note that Reading Museum possesses a copy in needlework of the famous Bayeux tapestry, executed by the Leek Needlework Society. We remember that when we last saw the original at Bayeux it had suffered mutilation by a relic-hunter, and the three-cornered piece which had been snipped out, having come into possession of the South Kensington Museum, had been returned to Bayeux, but instead of being replaced in position it was mounted separately on a block. Perhaps it has since taken its proper place in the tapestrv and the modern piece which had been worked in been removed.

An important portion of the business of the congress was the complete revision of the rules, which after discussion were passed as presented by the council.

\title{
The Orientation of the Dead.
}

$A^{T}$ a meeting of the Royal Anthropological Institute, A. held on May 3I, Prof. H. J. Rose read a paper on "Celestial and Terrestrial Orientation of the Dead." Two forms of orientation were distinguished and illustrated by examples; namely, graves orientated $(a)$ on a point in the heavens, as the east; (b) on a point on the surface of the earth, e.g., Mecca. The former Prof. Rose called celestial, the latter terrestrial, orientation. The deciding factor was normally the point towards which the face of the buried corpse turned. This point was often the former habitat, whether real or supposed, of the dead man's people.

The author compared the custom, common among many peoples, of burying in or near the hut, or facing towards the supposed home of the man's spirit at or before birth. This was combined with a belief in reincarnation : the ghost, feared and avoided as such, was welcomed when it became a baby, born of a woman of its own clan or tribe; but as the rebirth of some persons, e.g. notorious criminals, was not desired, means were taken to place their bodies in such a position that the ghost would get lost. Thus only the desirable people were buried in the normal place or with the normal orientation towards the dwellingplace of their potential mothers or towards Hades, whence in many cases the souls of the new-born come.

Belief in reincarnation, however, need not of necessity lead to the practice of orientation. NO. 2695 , VOL. IO7 7
Celestial orientation was not always possible in low grades of culture which might have no knowledge of anv such thing as cardinal points. Where celestial orientation existed such knowledge could not be assumed without further evidence. It might indicate (a) the departure of the dead to a land of darkness, marked by the position of the setting sun; $(b)$ the departure to a land of light, marked by sunrise. Moreover, as some were too bad to be wanted back on earth, some also (e.g., import. ant chiefs) were too exalted ever to become babies again. Hence to find a cemetery containing a number of bodies most of which face to one quarter while a considerable number face to another rather proved than disproved deliberate orientation. This applies, for example, to the burial-ground of Megara Hvblæa.

Orientation E.-W. was frequently accompanied by orientation N.-S. Houses were frequently constructed so as to facilitate observation of the position of the sun. If this was done, it was a matter of indifference whether the house $\operatorname{ran}$ N.-S. or E.-W. The grave was regarded as the house of the dead.

Another possibility was that the grave, as a sleeping place, was so arranged that the rising sun would warm and vivify the sleeper. This apnlies only to the E.-W. position.

The idea of the journey of souls to a place on earth, ublishingärouptant, may often be distinguished from 
celestial orientations $(a)$ by the fact that they tend to converge, not to diverge, in direction; $(b)$ by the absence of graves at right angles to the prevailing direction.

They may also be orientated by being placed along a road of spirits. There were three main classes of non-orientated burials, those with $(a)$ an absence of any intelligible arrangement whatsoever, as in the British round barrows, (b) a funeral feast arrangement, as among the Siculi and some Amerindians, (c) a "Sociocentric" arrangement, as among the Wotjobaluk, Omaha, Ponka, etc.

In conclusion, Prof. Rose suggested that if his deductions were sound, they afforded, inter alia, a new test of race.

In the discussion which followed the reading of the paper Dr. Rivers, the president, pointed out that Prof. Rose, in coupling reincarnation and terrestrial orientation, had suggested an entirely new con- nection. In Melanesia orientation was usually terrestrial. There was, however, a form of orientation which, while being celestial, had no connection with the cardinal points. It was in the direction of a home of the dead in the sky, which he connected with the Melanesian variant of upright burial and the custom of burying the dead in the sea with weights attached to their legs. Dr. Rivers suggested, further, that our own practice of laying the corpse on its back may be connected with the home of the dead in the sky. Prof. Elliot Smith referred to the custom of the protodynastic Egyptians who buried their dead with the head to the south, while in the second and third dynasties they were buried with the head to the noth, in each case towards the country of origin. Mr. H. Peake pointed out that the terrestrial orientation would tend to become celestial as a people in the course of its wanderings lost the memory of the direction of its original point of departure.

\section{The National Academy of Sciences, U.S.A.}

THE annual meeting of the National Academy of Sciences was held at the Smithsonian Institution on April 25-27. Unusual interest was taken in the meetings owing to the presence of his Serene Highness Albert I., Prince of Monaco, Prof. and Mrs. Albert Einstein, and Dr. Frank Adams, of Montreal, a foreign associate. In accordance with a precedent of long standing, President Harding received the academy.

On Monday evening, April 25, the Prince of Monaco gave an address, illustrated by moving pictures, on his researches in oceanography, for which the Agassiz medal, founded by the late Sir John Murray, was awarded to him by the academy in 19I8. After the address the Prince graciously received the members of the audience at a reception held in the National Gallery of Art.

On Tuesday the president, Dr. C. D. Walcott, extended a welcome to Prof. Albert Einstein on behalf of the academy, to which Prof. Einstein briefly responded, expressing his sense of pleasure at being present at the meeting of the academy and receiving its welcome.

On Tuesday evening, at the annual banquet, the presentation of the academy's medals was made. The Mary Clark Thompson medal, for eminence in researches in palæontology and geology, was awarded for the first time to Dr. Walcott for his classic studies in Cambrian palæontology. The A'gassiz medal for Jois was presented to the Prince of Monaco. The Agassiz medal for I02I was presented to Admiral Sigsbee for his investigations, including deep-sea soundings and other oceanographic work, mainly in the Gulf of Mexico. The Henry Draper gold medal, for eminence in astronomical physics, was awarded to Prof. P. Zeeman, of Amsterdam, for his discovery of the socalled "Zeeman effect" and for the study of the influence of magnetism upon light. In Prof. Zeeman's absence the medal was communicated through Dr. Hubrecht, secretary of the Netherlands Legation. The Daniel Giraud Elliot medal was awarded to Dr. Robert Ridgway for his studies of the birds of North America, especially part viii. of his "Birds of North and Middle America," which has recently appeared. The Hartley gold medal for eminence in the application of science to the public welfare was awarded to Dr. C. W. Stiles for his work in the investigation and eradication of the hookworm disease in the United States.

At the business meeting on Wednesday, April 27, Dr. Walcott tendered his resignation as president of the academy on account of, his desire to lay down NO. 2695 , VOL. IO7] something of the burden of administrative work which he has long carried, and in order to be able to devote himself more completely to his studies of palæontology, but at the unanimous desire of the academy he consented to withdraw his resignation for the remaining two years of his term. Dr. George E. Hale resigned the office of foreign secretary on account of ill-health, and Dr. R. A. Millikan was elected to succeed him. Messrs. Hale and Pearl were elected to the council, and the following new members were elected to the academy: Messrs. Frank Michler Chapman, William Leroy Emmet, William Draper Harkins, Ales Hrdlicka, Arthur Edwin Kennelly, William George MacCallum, Dayton Clarence Miller, George Abram Miller, Benjamin Lincoln Robinsón, Vesto Melvin Slipher, Lewis Buckley Stillwell, Donald Dexter Van Slyke, Thomas Wayland Vaughan, Henry Stephens Washington, and Robert Sessions Woodworth.

Numerous papers were presented at the scientific sessions. The principal feature was the address of Dr. W. S. Adams, of Mount Wilson Solar Observatory, on his spectrum researches on the motions in the line of sight and the absolute magnitudes of nearly 2000 stars. Dr. Adams pointed out the excellent confirmation of Russell's theory of giant and dwarf stars, and discussed the bearing of the observations on the dependence of stellar velocities upon spectral type and absolute magnitude. He also treated several other questions which are no longer insoluble now that, for the first time, the positions, directions, and velocities in space of such a large and homogeneous mass of stars have become known.

Dr. C. D. Walcott gave a profusely illustrated paper in which he directed attention to the great detail in the structure of the trilobite which he has found by the application of a new photographic process.

Dr. H. F. Osborn, of the American Museum of Natural History, New York, traced the evolution and geographical distribution of the Proboscidea. The two main groups of the mastodons and true elephants were followed, by the aid of skeletal photographs, restorations, and maps, from their original homes in northern Africa and Central Asia in the Eoceñe through their migrations over Europe and Asia to North and South America by way of Bering Strait.

Another paper of the same general character was given by Dr. J. C. Merriam, president of the Carnegie Institution, on his twenty vears of study of the evolution and geographical distribution of the bear family.

Dr. L. R. Jones, of the University of Wisconsin. showed the pathological influence of temperature, and 